\title{
A review of evapotranspiration estimates from tropical forests in Thailand and adjacent regions
}

\author{
Nobuaki Tanaka ${ }^{a, *}$, Tomonori Kume ${ }^{b}$, Natsuko Yoshifuji $^{c, d}$, Katsunori Tanaka ${ }^{e}$, \\ Hideki Takizawa $^{f}$, Katsushige Shiraki ${ }^{g}$, Chatchai Tantasirin ${ }^{h}$, \\ Nipon Tangtham ${ }^{h}$, Masakazu Suzuki ${ }^{d}$
}

${ }^{a}$ University Forest in Aichi, Graduate School of Agricultural and Life Sciences, The University of Tokyo, 11-44 Goizuka, Seto, Aichi 489-0031, Japan

${ }^{\mathrm{b}}$ Kasuya Research Forest, Kyushu University, Sasaguri, Fukuoka 811-2415, Japan

'Japan Science and Technology Agency, 4-1-8 Honcho, Kawaguchi, Saitama 332-0012, Japan

${ }^{\mathrm{d}}$ Graduate School of Agriculture and Life Sciences, The University of Tokyo, 1-1-1 Yayoi, Bunkyo-ku, Tokyo 113-8657, Japan

${ }^{\mathrm{e}}$ Frontier Research Center for Global Change, Japan Agency for Marine-Earth Science and Technology, 3173-25 Showamachi, Kanazawa-ku, Yokohama, Kanagawa 236-0001, Japan

${ }^{\mathrm{f}}$ College of Bioresource Sciences, Nihon University, 1866 Kameino, Fujisawa, Kanagawa 252-8510, Japan

${ }^{\mathrm{g}}$ Department of Ecoregion Sciences, Faculty of Agriculture, Tokyo University of Agriculture and Technology, 3-5-8 Saiwaimachi, Fuchu, Tokyo 183-8509, Japan

${ }^{\mathrm{h}}$ Faculty of Forestry, Kasetsart University, Chatuchuk, Bangkok 10900, Thailand

\section{A R T I C L E I N F O}

Keywords:

Evapotranspiration estimates

Dry season evapotranspiration

Tropical monsoon forests

Rooting-depths

Inter-annual fluctuation in

rainfall regime

\begin{abstract}
A B S T R A C T
To understand the potential roles of seasonally dry tropical forests (tropical monsoon forests) of mainland Southeast Asia in the regional climate system, we briefly describe the complex forest types in this region and review published studies which reported water vapour exchange between tropical monsoon forests and the atmosphere. In addition, we propose future research needs to address deficiencies in our current knowledge base. Seasonal variation in atmospheric evaporative demand, which generally increases with atmospheric water vapour deficit and incoming solar radiation, is conspicuous in this monsoon region, reaching maxima in the late dry season and relatively low values in the wet season. Though the number of reviewed studies is limited, a comparison of seasonal patterns of evapotranspiration (ET) between forest types shows increased ET corresponding with the atmospheric evaporative demand in two evergreen forest ecosystems, but not in both an evergreen and two deciduous forest ecosystems. This contrasting ET seasonality results in considerable differences in dry season ET among forest types, ranging from a low of $0.6 \mathrm{~mm} \mathrm{~d}^{-1}$ at one evergreen forest type, to $5.9 \mathrm{~mm} \mathrm{~d}^{-1}$ at another evergreen forest type. Further investigations of both rooting-depths and responses of stomatal conductance of individual trees to dry conditions are suggested to be necessary to draw a more general conclusion regarding dry season ET difference between forest types. Besides the seasonal changes in evaporative demand, inter-annual fluctuations of rainfall and its seasonal distribution are also significant in this region. Recent phenological and physiological studies suggest that these inter-annual variations in rainfall can have significant impacts on water and energy exchanges above the tropical monsoon forests. Thus, we stress the need for further examination of the effects of rainfall-regime anomalies on water and energy exchanges between tropical monsoon forests and the atmosphere.
\end{abstract}

(C) 2008 Elsevier B.V. All rights reserved.

\footnotetext{
* Corresponding author. Tel.: +81 56182 2371; fax: +81 561852838.

E-mail address: tanaka@uf.a.u-tokyo.ac.jp (N. Tanaka).
} 


\section{Introduction}

Tropical forests are recognised as terrestrial ecosystems that exert significant influences on regional and global energy and water cycling (e.g., Malhi et al., 2002; Choudhury et al., 1998) because they comprise $60 \%$ of all global forest areas (FAO, 2001), and are located in regions of high solar radiation and evaporation. In Southeast (SE) Asia, anthropogenic deforestation of tropical forests since the last century has led to rapid declines in forest area (Laurance, 1999). Meso-scale and global climate model simulations have been used to examine the effects of such land cover changes on regional and global climate (e.g., Henderson-Sellers et al., 1993; Zhang et al., 1996; Mabuchi et al., 2005a,b; Kanae et al., 2001). Early simulation efforts reported that deforestation in SE Asia had less impact on regional climate, than did deforestation in Amazonian rainforests (Henderson-Sellers et al., 1993; Zhang et al., 1996). However, more recent experiments using climate models with finer resolution have implied that deforestation in SE Asia alters Asian monsoon circulation (Mabuchi et al., 2005a,b) and regional precipitation (Kanae et al., 2001). These results suggest a need for a better understanding of how tropical forests in SE Asia contribute to the partitioning of incoming energy and water into the atmosphere and how such partitions are controlled by environmental changes such as intra- and inter-annual fluctuations in climate.

The Asian tropics contain numerous types of forest ecosystems (Whitmore, 1984; Ashton, 1995; Kira, 1983; Rundel and Boonpragob, 1995; Ogawa et al., 1961; Ohsawa, 1993), the distribution of which depends on factors such as climate, soil properties, and topography. In addition, due mainly to high population pressure in this region, these forest ecosystems have been substantially altered to other types of forest vegetation such as secondary regrowth and tree plantations, or converted to non-forest land covers such as pasture, paddies, and cropland. A typical rainforest type in SE Asia, lowland mixed dipterocarp forests in areas without a distinct dry period, have been well studied in terms of water and energy exchanges with the atmosphere using both traditional micrometeorological techniques (Calder et al., 1986; Takanashi et al., 2003; Tani et al., 2003a), and the eddy covariance method (Kumagai et al., 2004, 2005; Takanashi et al., 2005). However, less is known about these topics for seasonally dry forest ecosystems in the Asian tropics, which are prone to an annual dry period of low rainfall. Thailand and other countries of the Indochina Peninsula constitute the centre of biodiversity for the Indo-Burma region (Ashton, 1990), having widespread tropical seasonal forests and various types of floristic compositions (e.g., Rundel and Boonpragob, 1995; Ogawa et al., 1961; Santisuk, 1988). Because ecological factors such as stand structure, phenology, and physiology differ largely among the forest types, there is a need to systematically investigate material exchanges for each forest type to gain an encompassing understanding of the roles of forests at local-to-global scales.

The onset of the Asian monsoon and the start of the wet season tend to be delayed in the Indochina Peninsula, in association with El Niño Southern Oscillation (ENSO) events (Zhang et al., 2002). Furthermore, associated with ENSO events, annual rainfall is likely to be reduced (e.g., Malhi and Wright, 2004). The concomitant dry conditions are followed by lowered normalised difference vegetation index (NDVI) values, and higher surface temperatures in this region (e.g., Nishida et al., 2005). This implies that, besides the seasonal climatic fluctuations brought by an annual cycle of the Asian monsoon, inter-annual fluctuations in the rainfall regime influence material exchanges between the seasonally dry tropical forests and the atmosphere. Therefore, for a general understanding of the roles of forests in the climate system, we need to address the responses of seasonally dry tropical forests to climatic changes at seasonal and interannual timescales.

In this publication, we first summarise the composition of tropical monsoon forests in Thailand and adjacent regions (Section 2). We then review published studies related to ET estimation both at seasonal (Section 3) and inter-annual timescales (Section 4). Taking the current status of knowledge into account, we end with proposals for future research (Section 5).

\section{Tropical monsoon forests in Thailand and adjacent regions}

\subsection{Microclimates}

The synoptic climate of mainland SE Asia is predominantly affected by an annual cycle of the Asian monsoon, with defined wet and dry seasons (Matsumoto, 1997). This seasonal climate differs from that prevailing south of the KangarPattani Line in Malaysian Peninsula (Fig. 1; Whitmore, 1984) where rainfall is evenly distributed throughout the year. Because the Kangar-Pattani Line nearly matches the political boundary between Thailand and Malaysia (Fig. 1), the forests of mainland SE Asia are, more or less, prone to an annual dry period with soil water stress. We refer to such seasonally dry forests in this region as "tropical monsoon forests". Forest types and ecological properties of each are described in more detail in Section 2.2.

Microclimates of tropical monsoon forests vary with location and forest type. As examples of microclimates of tropical monsoon forests, seasonal changes in above-canopy meteorology obtained at a hill evergreen forest site (Kog-Ma) and a lowland teak deciduous forest site (Mae Moh) are shown in Fig. 2(a) and (b), respectively (see Fig. 1, Table 2, and Section 2.2 for detailed site information). Kog-Ma and Mae Moh receive mean annual rainfall of 1768 and $1387 \mathrm{~mm}$ year $^{-1}$, respectively. Such a rainfall difference between lowlands and uplands is commonly observed in this region (Kuraji et al., 2001). Although the amount of rainfall differs between the two sites, the seasonal distributions are quite similar (Fig. 2(a) and (b)). That is, rainfall occurs mainly during the wet season from May to October, while no significant rainfall is observed during the dry season from November to April. The typical monsoon circulation of a southwesterly moist air mass in the lower troposphere usually starts in mid-May (Matsumoto, 1997); however, some pre-monsoon rainfall (in March and April) is brought by meandering mid-latitude westerly winds (Kiguchi and Matsumoto, 2005). Incoming solar radiation at both sites is marginally depressed in the wet season and higher in the dry 


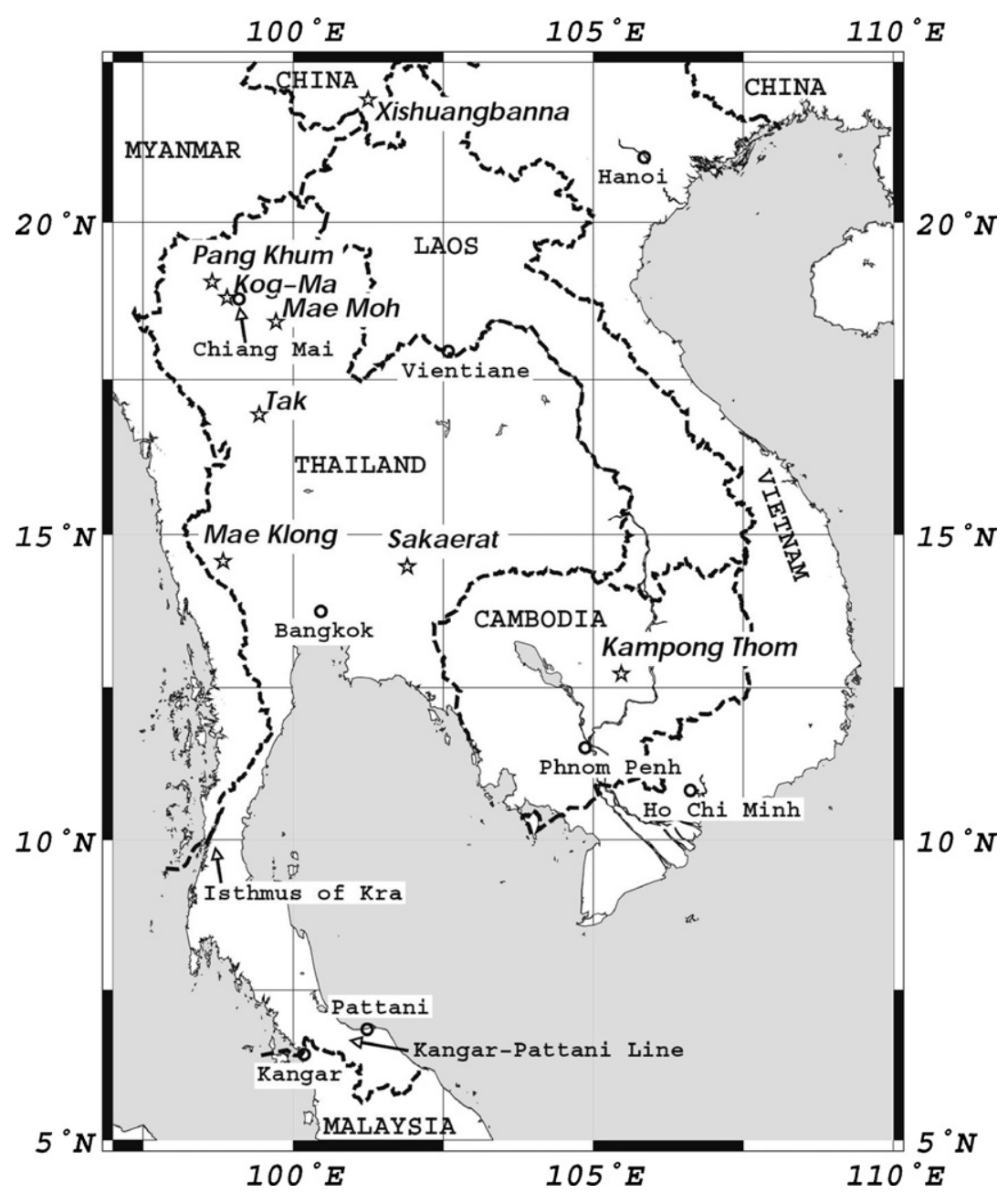

Fig. 1 - Map of mainland Southeast Asia. Study sites where flux observations have been conducted are indicated by stars. Major cities are shown by open circles. The floristically important boundaries of the Kangar-Pattani Line and the Ismusu of Kra (see text) are also indicated in the peninsula region. In addition to the reviewed study sites in this paper, the Xishungbanna flux study site of the ChinaFlux network and Mae Klong flux study site of the AsiaFlux network are also plotted on the map.

season (Fig. 2(a) and (b)). At the upland site of Kog-Ma, solar radiation is maximised in the late dry season (March and April) because of reduced cloudiness, increased day length and solar altitude, whereas the peak is ambiguous at Mae Moh. The mean annual air temperature in Kog-Ma (ca. $20^{\circ} \mathrm{C}$ ) is lower than that in Mae Moh (ca. $25^{\circ} \mathrm{C}$ ) because of an elevation effect. Air temperature at both sites is minimised in the early dry season of December and January, and is maximised in the late dry season of March and April. The hot season corresponds to the period when the daily mean atmospheric vapour pressure deficit (VPD) peaks at approximately $12 \mathrm{hPa}$ for Kog-Ma and $22 \mathrm{hPa}$ for Mae Moh (Fig. 2). This high atmospheric VPD level in the late dry season may be one noteworthy characteristic of microclimates of tropical monsoon forests. In fact, the daily mean VPD rarely exceeds $10 \mathrm{hPa}$, roughly equivalent to a specific humidity deficit of $6.2 \mathrm{~g} \mathrm{~kg}^{-1}$, at lowland mixed dipterocarp forests in SE Asia (Tani et al., 2003a; Takanashi et al., 2005; Kume, 2005) and in terra firme rainforests at the Amazon Basin (Rocha et al., 2004; Carswell et al., 2002; von
Randow et al., 2004). The severe dry conditions of tropical monsoon forests in this season are likely similar to those of transitional tropical forests in the Brazilian Amazon (e.g., Vourlitis et al., 2001). Fig. 2(c) and (d) illustrate additional microclimate data available for two other lowland forest sites in this region, a disturbed dry dipterocarp forest site at Tak and a dry evergreen forest site at Sakaerat, respectively (see Fig. 1, Table 2, and Section 2.2 for detailed site information). Though the data is discontinuous (Fig. 2(c)) or monthly (Fig. 2(d)), the same seasonal patterns of microclimates as shown above (Fig. 2(a) and (b)) can be found for the two forest sites. Note that relatively high temperature and VPD in March 1999 at Tak site might be a result of the 1997-1998 ENSO event. Although there are discrepancies in amplitudes of seasonal fluctuations in meteorological variables between sites, the atmospheric demands that force evapotranspiration from forest vegetations have the same seasonality; that is, the demand is maximised in the late dry season and lowered in the wet season. 


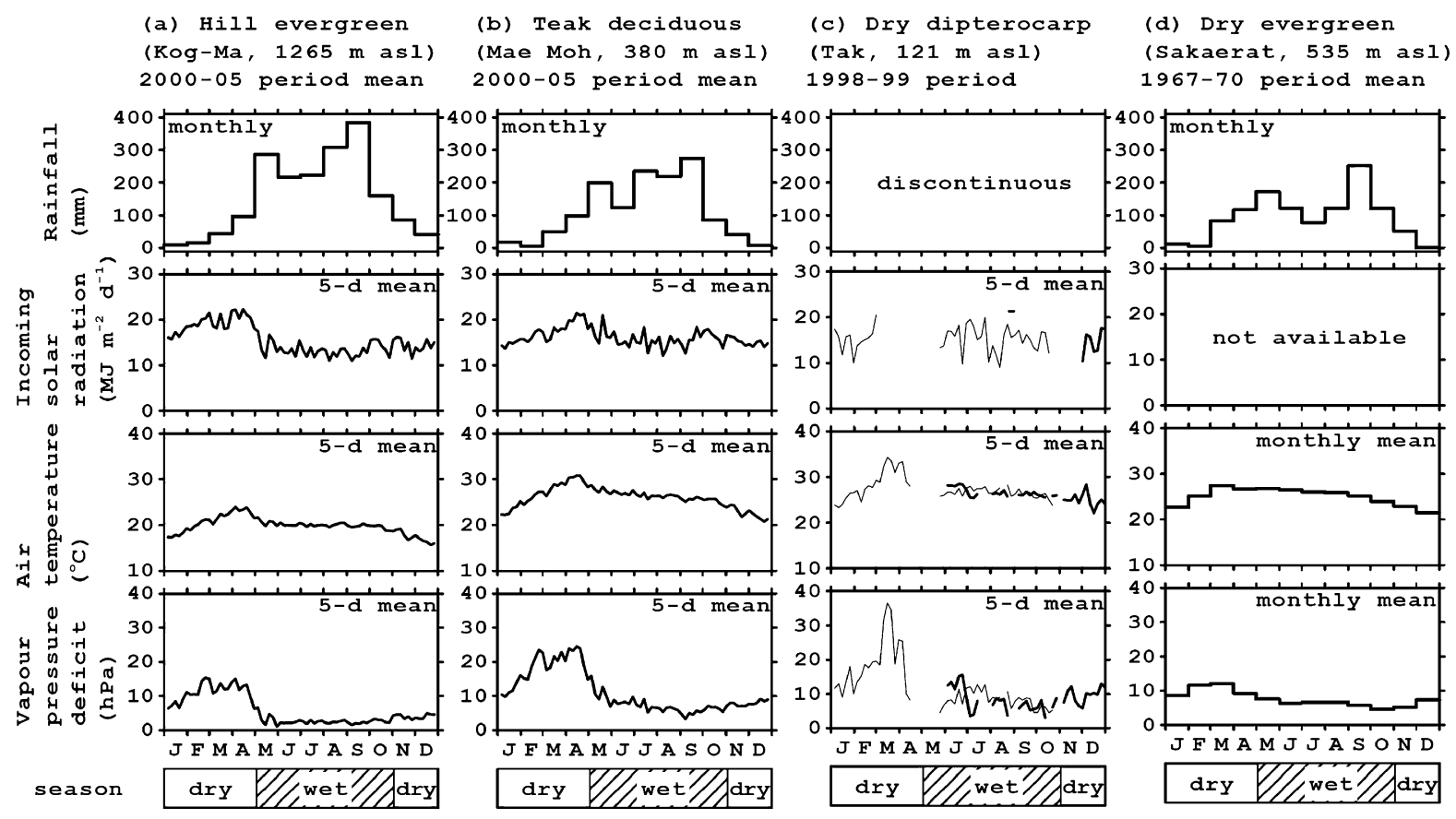

Fig. 2 - Seasonal changes in above-canopy micrometeorology of tropical monsoon forests. Monthly rainfall, 5-d mean solar radiation, 5-d mean air temperature, and 5-d mean vapour pressure deficit (VPD) at (a) a hill evergreen forest site at Kog-Ma for the 2000-2005 period, (b) a teak deciduous forest site at Mae Moh for the 2000-2005 period, and (c) a disturbed dry dipterocarp forest site of Tak in 1998 (thick line) and in 1999 (thin line). Also shown are (d) monthly rainfall, monthly mean air temperature, and monthly mean VPD at a dry evergreen forest site of Sakaerat for the 1967-1970 period (Pinker et al., 1980). The data at the Tak forest site is available at http://hydro.iis.u-tokyo.ac.jp/GAME-T/.

\subsection{Forest cover and classification}

Thailand experienced a rapid decline in forested area during the last century (e.g., Myers, 1994; Hirch, 1990). At the beginning of the 1900s, forests covered as much as $75 \%$ of Thailand; however, forest cover had decreased to $53 \%$ by 1961 and to $25 \%$ by 1982 (Hirch, 1987). The current forest cover is approximately 33\% (NWPCD, 2000). Geographically, forests are not evenly distributed throughout the country. For example, northern Thailand has about three times as much forest cover (59\%) as the northeast (16\%; NWPCD, 2000), an imbalance that likely reflects differences in human pressures and accessibilities among the regions.

Our region of focus includes five distinct forest types: dry evergreen forest, dry dipterocarp forest, mixed deciduous forest, hill evergreen forest, and tropical wet evergreen forest (Table 1). Because detailed accounts of the ecology and biogeography of individual types have been given elsewhere (see Ashton, 1990; Ashton, 1995; Kira, 1983; Ogawa et al., 1961; Ogawa et al., 1965; Ogino, 1976; Pendleton, 1962; Rundel and Boonpragob, 1995; Ruangpanit, 1995; Santisuk, 1988), we provide only brief descriptions of each type of tropical monsoon forest. Note that we mainly refer to the forest names and classifications used by Santisuk (1988) or Rundel and Boonpragob (1995), whose reports contain the most encompassing descriptions both of upland and lowland forest ecosystems.

Except in a lowland forest ecosystem of the mixed deciduous forest, the tree family Dipterocarpaceae dominates forested lowlands at altitudes less than $1000 \mathrm{~m}$ in this monsoon region (Table 1). Three types of dipterocarp forests are identified. First, dry evergreen forest, which has a tall, dense canopy composed of diverse tree species, is a droughttolerant evergreen forest experiencing an annual dry period of 4-6 months. Second, dry dipterocarp forest is a relatively short and open deciduous forest type with canopy trees belonging to only a few species of the genera Shorea and Dipterocarpus (Table 1). Interestingly, dry dipterocarp forest occurs in the same climate as dry evergreen forest. Mosaic-like or side-byside distributions of the dry evergreen and dry dipterocarp forest, under the same climate conditions, are a prominent characteristic of lowland forests in mainland SE Asia (Blasco, 1983). This distribution pattern partly reflects complex topographic and soil properties (Pendleton, 1962). In addition, annual anthropogenic ground fires likely affect the distribution (Blasco, 1983; Stott et al., 1990). Third, tropical wet evergreen forest is a species-rich, Dipterocarpaceae-dominated forest type characterised by a tall and dense evergreen canopy (Kira, 1983; Ogawa et al., 1965). While both dry evergreen and dry dipterocarp forests extend over the lowlands in mainland SE Asia, the spatial distribution of tropical wet evergreen forest is restricted to an area between the Kangar-Pattani Line to the Isthmus of Kra in the Malaysian Peninsula (Fig. 1), where the climate is transitional from monsoonal to equatorial, and the dry season typically lasts between 1 and 3 months (Ashton, 1995). Tropical wet evergreen forest differs from the well-known lowland mixed dipterocarp forests in the equatorial SE Asia. As Ashton (1995) 
Table 1 - Classification of tropical monsoon forests in Thailand and adjacent regions

\begin{tabular}{|c|c|c|c|c|c|}
\hline \multirow[t]{2}{*}{ Forest type } & \multirow[t]{2}{*}{$\begin{array}{c}\text { Dry season } \\
\text { length (month) }\end{array}$} & \multirow[t]{2}{*}{$\begin{array}{l}\text { Deciduousness } \\
\text { on a stand scale }\end{array}$} & \multirow{2}{*}{$\begin{array}{l}\text { Altitudinal } \\
\text { distribution }^{a} \\
\text { (m a.s.l.) }\end{array}$} & \multicolumn{2}{|c|}{$\begin{array}{l}\text { Floristic composition } \\
\text { of canopy trees }\end{array}$} \\
\hline & & & & Dominant family & Typical species \\
\hline Dry evergreen forest & $4-6$ & Evergreen & $<1000$ & Dipterocarpaceae & $\begin{array}{l}\text { Hopea odorata, H. ferrea, } \\
\text { Dipterocarpus turbinatus, D. constatus }\end{array}$ \\
\hline Dry dipterocarp forest & $4-6$ & Fully deciduous & $<1000$ & Dipterocarpaceae & Shorea obtuse, D. obtusifolis \\
\hline $\begin{array}{l}\text { Tropical wet } \\
\text { evergreen forest }\end{array}$ & $1-3$ & Evergreen & $<1000$ & $\begin{array}{l}\text { Dipterocarpaceae } \\
\text { Myrtaceae }\end{array}$ & $\begin{array}{l}\text { Dipterocarpus spp. }{ }^{\mathrm{b}} \\
\text { Eygenia clarkeana }\end{array}$ \\
\hline Mixed deciduous forest & $4-6$ & Partially deciduous & $<1000$ & $\begin{array}{l}\text { Vervenaceae } \\
\text { Leguminoceae }\end{array}$ & $\begin{array}{l}\text { Tectona grandis (teak) } \\
\text { Pterocarpus macrocarpus, Xylia kerrii }\end{array}$ \\
\hline Hill evergreen forest & $4-6$ & Evergreen & $>1000$ & $\begin{array}{l}\text { Lauraceae } \\
\text { Fagaceae } \\
\text { Theaceae }\end{array}$ & $\begin{array}{l}\text { Cinnamomum porrectum } \\
\text { Lithocarpus elegans, Castanopusis } \\
\text { acuminatissima } \\
\text { Schima wallichii }\end{array}$ \\
\hline
\end{tabular}

noted, the tropical wet evergreen forests are differentiated as "seasonal mixed evergreen dipterocarp forests", because of the relatively low species richness in tropical wet evergreen forest compared to the lowland mixed dipterocarp forest.

Mixed deciduous forest is an indigenous ecosystem of the northern margin of the lowland Indochina Peninsula (i.e., India, Myanmar, and northwestern Thailand; Rundel and Boonpragob, 1995). This ecosystem is frequently referred to as "teak forest" because of the dominance of Tectona grandis (Ashton, 1995; Kira, 1983; Pendleton, 1962). This type of forest has multistoried, tall vegetation, potentially including not only $\mathrm{T}$. grandis but also other diverse canopy tree species (Table 1). Unlike dry dipterocarp forest, the mixed deciduous forest is not fully deciduous on a stand scale; however, most middle- and uppercanopy trees shed their leaves in the dry season (Kira, 1983; Santisuk, 1988). Because of the commercial importance of teak timber, selective extractions of teak from mixed deciduous forest took place from the early part of the last century until 1987, when logging of natural forests was prohibited by law (Hirch, 1987, 1990). Because of past logging, once diverse forests have become floristically impoverished (i.e., mixed deciduous forest without teak). Instead, teak is now prevalent as a plantation tree in this region (Krishnapillay, 2000).

Hill evergreen forest is typical in upland areas above $1000 \mathrm{~m}$ in altitude, where all Dipterocarpaceae might disappear. This forest type is dominated by the tree family such as Fagaceae, Lauraceae, and Theaceae. Alternatively referred to as laurofagaceous forest, hill evergreen forest extends throughout mountainous areas of the Asian tropics from the eastern Himalayan foothills to Papua New Guinea (Ohsawa, 1993, 1995). The stand structure is characterised by a tall and complex evergreen canopy. Because such forests are sometimes above the cloud base, moisture inputs from cloud water interception by the canopy may be significant to sustain the ecosystem (Werner and Santisuk, 1993; Tanaka et al., in press). While logging of natural forests is prohibited in Thailand, shifting or slash-and-burn cultivation by ethnic groups in the uplands remains common (e.g., Santisuk, 1988). Because of these activities, a typical upland landscape in this region is a vegetation mosaic, including primary hill evergreen forests, secondary forests with different ages, and croplands (Giambelluca, 2002).

\section{Seasonality of evapotranspiration}

\subsection{Studied and unstudied forest types}

The five forest biomes listed in Table 1 differ not only in floristic compositions but also in other ecological features such as stand structure, which includes canopy height and tree density; phenology, which determines the stand-scale deciduousness and seasonality of the leaf area index (LAI); physiology such as stomatal behaviour; soil conditions such as soil hydrologic properties. Because water and energy exchanges above the forest canopy are largely controlled by all these properties, we review them by forest type in the following subsections.

Table 2 lists all the published studies that have examined ET from tropical monsoon forests, indicating the study site information such as forest types, study periods and measurement techniques for estimating ET. To examine ET seasonality for each forest type, Fig. 3 compares the reported monthly ET values. Note that, in Fig. 3, ET seasonality reported by Nobuhiro et al. (2007) for a dry evergreen forest is not included, because we could not obtain the ET values from a figure showing daily ET in their paper. Instead, we visually obtained approximate ET values from the figure showing daily ET (see Section 3.3). For the same reason, we could not show the ET seasonality at a teak deciduous forest studied by Attarod et al. (2006). However, they explicitly indicated the maximum and minimum mean monthly ET values in their text. We thus plotted those ET values in Fig. 3.

As shown in Table 2, the studied forest types do not entirely cover all the forest types in Table 1. Of the five tropical monsoon forest ecosystems, ET has not yet been examined at three ecosystems: the (undisturbed) dry dipterocarp forest, tropical wet evergreen forest, and (typical) mixed deciduous forest. Therefore, we do not refer to ET characteristics of the three unstudied forest ecosystems in the following subsections. 
Table 2 - Study sites where evapotranspiration from tropical monsoon forests have been examined

\begin{tabular}{|c|c|c|c|c|c|c|}
\hline Study site & $\begin{array}{l}\text { Location } \\
\text { (latitude, } \\
\text { longitude) }\end{array}$ & $\begin{array}{l}\text { Altitude } \\
\text { (m a.s.l.) }\end{array}$ & Forest type & Study period & Method $^{\mathrm{a}}$ & References \\
\hline Sakaerat & $14^{\circ} 29^{\prime} \mathrm{N}, 101^{\circ} 54^{\prime} \mathrm{E}$ & 535 & Dry evergreen forest & January and June 1970 & GR & Pinker et al. (1980) \\
\hline Kampong Thom & $12^{\circ} 44^{\prime} \mathrm{N}, 105^{\circ} 28^{\prime} \mathrm{E}$ & 88 & Dry evergreen forest & November 2003-October 2004 & $\mathrm{BR}$ & $\begin{array}{l}\text { Nobuhiro } \\
\text { et al. (2007) }\end{array}$ \\
\hline Tak & $16^{\circ} 56^{\prime} \mathrm{N}, 99^{\circ} 26^{\prime} \mathrm{E}$ & 121 & $\begin{array}{l}\text { Disturbed dry dipterocarp } \\
\text { forest }^{\mathrm{b}}\end{array}$ & July 1998-February 1999 & ED & Toda et al. (2002) \\
\hline Mae Moh & $18^{\circ} 25^{\prime} \mathrm{N}, 99^{\circ} 43^{\prime} \mathrm{E}$ & 380 & $\begin{array}{l}\text { Teak deciduous forest } \\
\text { or reforested mixed } \\
\text { deciduous forest }\end{array}$ & May 1999-December 2004 & $\mathrm{BR}$ & Attarod et al. (2006) \\
\hline Kog-Ma & $18^{\circ} 48^{\prime} \mathrm{N}, 98^{\circ} 54^{\prime} \mathrm{E}$ & 1265 & Hill evergreen forest & January 1998-December 1999 & $E D^{c}$ & Tanaka et al. (2003) \\
\hline Pang Khum & $19^{\circ} 03^{\prime} \mathrm{N}, 98^{\circ} 39^{\prime} \mathrm{E}$ & 1250 & $\begin{array}{l}\text { Hill evergreen forest } \\
\text { (8-year secondary growth) } \\
\text { Hill evergreen forest } \\
\text { (25-year secondary growth) }\end{array}$ & $\begin{array}{l}\text { January 1993-March } 1993 \\
\text { April and May } 1993\end{array}$ & $E B^{d}$ & $\begin{array}{l}\text { Giambelluca } \\
\text { et al. (2000) }\end{array}$ \\
\hline \multicolumn{7}{|c|}{$\begin{array}{l}\text { a The nomenclatures are as follows: ED, eddy covariance method; BR, Bowen ratio method; GR, gradient method; EB, energy balance method. } \\
\text { b This vegetation is composed mainly of the dry dipterocarp forest, but is partly used by humans as paddy fields, croplands, glasslands and } \\
\text { water reservoirs. } \\
\text { c This study was basically based on a SPAC model simulation, output of which was carefully validated with observations (see text in Section } \\
\text { 3.2.1). } \\
\text { d Sensible heat flux was observed by an aerodynamic approach, and latent heat was estimated by considering the energy balance equation } \\
\text { (see text in Section 3.2.2). }\end{array}$} \\
\hline
\end{tabular}

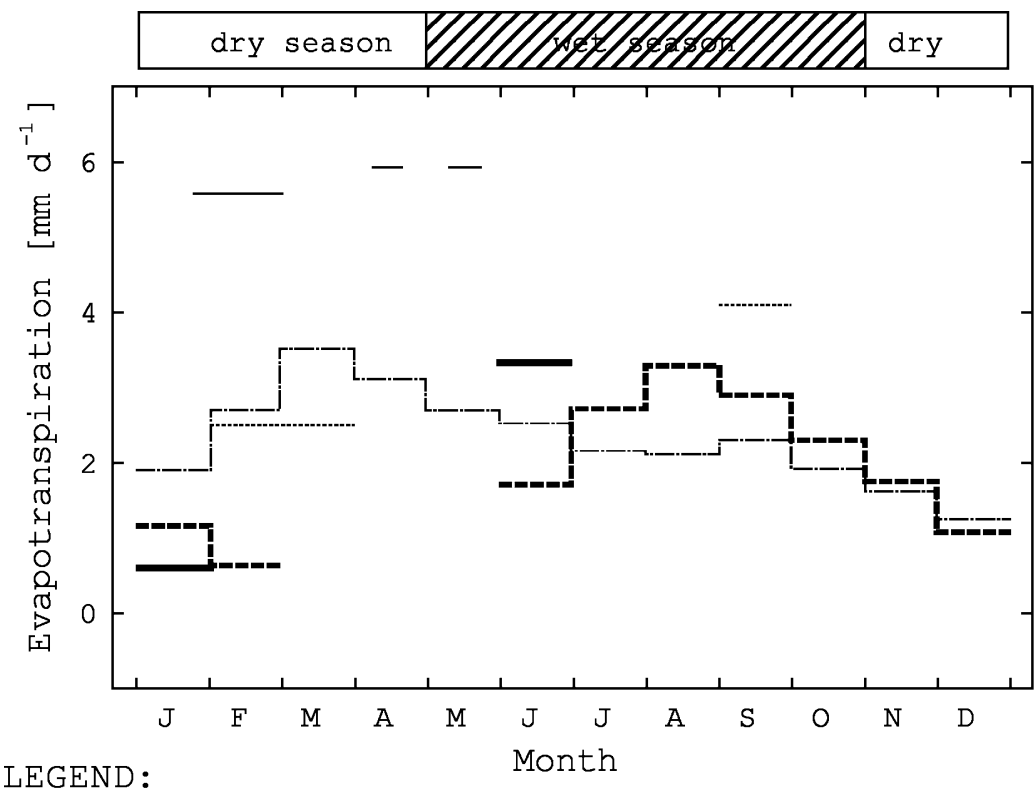

LEGEND :

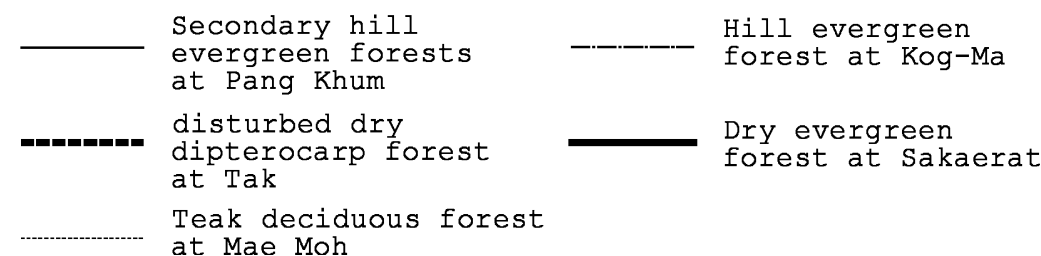

Fig. 3 - Seasonal changes in evapotranspiration (ET) estimates from tropical monsoon forests. Indicated are the averaged ET estimates from a hill evergreen forest for the 1998-1999 period (thin dashed line; Tanaka et al., 2003), secondary hill evergreen forests in 1993 (thin solid line; Giambellucca et al., 2000), a dry evergreen forest in 1970 (think solid line; Pinker et al., 1980), a disturbed dry dipterocarp forest from the June 1998 to February 1999 (thick dot line; Toda et al., 2002), and a teak deciduous forest for the 1999-2004 period (thin dot line; Attarod et al., 2006). Nobuhiro et al. (2007) also gave ET estimates from a dry evergreen forest in Cambodia. The ET values are not included in this figure (see Section 3.3). 


\subsection{Hill evergreen forest}

\subsubsection{Mature forest}

The seasonality of ET at a mature hill evergreen forest was modeled in Kog-Ma (see Fig. 1 and Table 2) during 1998-1999. There ET is approximately $2-3 \mathrm{~mm} \mathrm{~d}^{-1}$ in the wet season, 1$2 \mathrm{~mm} \mathrm{~d}^{-1}$ in early dry season, and reaches a maximum of 3$4 \mathrm{~mm} \mathrm{~d}^{-1}$ in the late dry season (Fig. 3). Although these ET figures were derived from numerical simulations using a soilplant-atmosphere continuum (SPAC) model (Tanaka, 2002) with observed physiological parameters for individual leaves of canopy trees, the simulated results agreed well with diurnal courses of heat and $\mathrm{CO}_{2}$ fluxes observed by the eddy covariance method during six short-term field campaigns, with observed seasonality in sap flow velocities of the canopy trees (Tanaka et al., 2003), and with rainfall interception (Tanaka et al., 2005). The simulated mean annual ET (812 $\mathrm{mm}$ year $^{-1}$ ) was identical to that derived from stream water gauging records $\left(812 \mathrm{~mm}\right.$ year $\left.^{-1}\right)$, and was close to a long-term historical figure (734 $\mathrm{mm}$ year $^{-1}$ ) shown by Chunkao et al. (1981). In addition, a recent study based on continuous long-term flux measurements using the eddy covariance method also revealed the same seasonal trend in ET (Kajiya, 2007). Of interest is the fact that no significant stomatal closure of canopy trees was observed in the late dry season when the soil (at depths of $0.1-0.5 \mathrm{~m}$ ) was extremely dry (Tanaka et al., 2003). These results suggest that ET at the hill evergreen forest corresponds roughly with the atmospheric evaporative demand (see Section 2.1); that there may be a source of moisture in deep soil layer even after a prolonged drought; and that rooting-depth may be deep enough to reach this moisture source.

Although directly observed evidence of this moisture source and the deep rooting-depth have not yet been reported for this forest ecosystem, several indirect results support this hypothesis (Kuraji et al., 2007; Shiraki, unpublished; Tanaka et al., 2004). First, gauge records of stream water drained from a small watershed of Kog-Ma indicate that, in the late dry season, discharge rate declined, but to no less than $1 \mathrm{~mm} \mathrm{~d}^{-1}$ (Kuraji et al., 2007), suggesting the presence of stored water in the subsoil layer. Second, Tanaka et al. (2004), using the abovementioned SPAC model with observed soil hydraulic parameters, inversely calculated the rooting depth in a hill evergreen forest, with which the above-mentioned ET peak in the late dry season could be reproduced; they concluded that rooting-depths of $4-5 \mathrm{~m}$ were needed to explain the ET seasonality. Third, direct measurements of soil depth were conducted using a cone penetrometer at 63 points in a small watershed at Kog-Ma. There soil depth was found to be $5.3 \mathrm{~m}$ on average, ranging from 1.7 to $13.0 \mathrm{~m}$ (Shiraki, unpublished). The mean depth was well within the range suggested by Tanaka et al. (2004). These three results strongly suggest that deep rooting-depth is a key factor controlling tree transpiration and thereby ET seasonality of hill evergreen forests.

\subsubsection{Secondary growth}

Water and energy exchanges between this forest type (see Section 2.2) and the atmosphere were examined at an upland site of Pang Khum in 1993 (see Fig. 1 and Table 2). Giambelluca et al. (2000) quantified the energy partitioning at Pang Khum and reported that in the dry season the ET rate was 5.6 and $5.9 \mathrm{~mm} \mathrm{~d}^{-1}$ at an 8- and a 25-year-old secondary hill evergreen forest, respectively (Fig. 3). In contrast, much lower ET values of $0.7,3.3,3.2,2.8 \mathrm{~mm} \mathrm{~d}^{-1}$ were observed in the same season for a harvested cropland, a fallow paddy field, a shrub field, and a grassland, respectively, where net radiation was partitioned into sensible heat, to varying degrees (Giambelluca et al., 2000). It should be noted that they measured the sensible heat flux by an aerodynamic approach, and the ET values (or latent heat flux) was computed as a residual term of the energy balance equation. Therefore, as they noted, their flux estimates may have greater uncertainty than those based on other techniques such as the eddy covariance method. However, they concurrently conducted stomatal resistance measurements of individual leaves and found a large difference in estimated canopy resistance between the secondary hill evergreen forests and other vegetation, supporting the observed large ET differences between the forests and other vegetation.

The dry season ET levels in secondary hill evergreen forests are much higher than the ET of $2.5-4 \mathrm{~mm} \mathrm{~d}^{-1}$ for mature hill evergreen forest (Fig. 3) and any previously reported annual mean ET for tropical rainforests in other regions; e.g., $3.9 \mathrm{~mm} \mathrm{~d}^{-1}$ for tropical forests overall (Bruijnzeel, 1990), $3.0 \mathrm{~mm} \mathrm{~d}^{-1}$ (Takanashi et al., 2005) and $4.2 \mathrm{~mm} \mathrm{~d}^{-1}$ (Kumagai et al., 2005) for lowland mixed dipterocarp forests in tropical SE Asia, and $3.6 \mathrm{~mm} \mathrm{~d}^{-1}$ (Shuttleworth, 1988) and $3.5 \mathrm{~mm} \mathrm{~d}^{-1}$ (Rocha et al., 2004) for terra firme rainforests in central and eastern Amazonia, respectively. Giambelluca et al. (2000) presumed that the elevated ET in the dry season was attributable to horizontally advected sensible energy from neighbouring patches such as bare lands and fallow fields. Indeed, the enhanced ET in a small patch of remnant forest has been verified by a transect measurement of sap flow at a montane site in Vietnam (Giambelluca et al., 2003). Giambelluca et al. (2000) also inferred that the elevated ET was supported by stored water in the subsoil, which trees in secondary hill evergreen forests (Lithocarpus elegans, see Table 1) can access by deep rooting. This inference is consistent with indirect evidence related to the deep root system revealed by the Kog-Ma studies mentioned above.

Taking the ET seasonality at the mature hill evergreen forest site of Kog-Ma (Section 3.2.1) into consideration, the enhanced ET at secondary hill evergreen forests in the dry season is expected to be lowered in the wet season. However, ET seasonality remains unknown because of their limited study period.

\subsection{Dry evergreen forest}

By applying a gradient method with roughness parameters observed by Thompson and Pinker (1975), Pinker et al. (1980) reported that ET at the Sakaerat forest (see Fig. 1 and Table 2) in 1970 was much higher in the wet period of June $\left(3.3 \mathrm{~mm} \mathrm{~d}^{-1}\right)$ than in the dry season of January (0.6 $\mathrm{mm} \mathrm{d}^{-1}$; Fig. 3) despite the fact that pan evaporation values for both months were almost identical. They suggested low moisture availability in January to be one possible reason for the conservative water use of the dry evergreen forest in that month. This is in part consistent with physiological features of a dominant canopy 
tree (Hopea ferrea, see Table 1) at the same site observed by Ishida et al. (2006), indicating lowered stomatal conductance during the dry season of December and February. Furthermore, the ET seasonality is likely to be consistent with the seasonality of carbon uptake by the Sakaerat forest. Gamo and Panuthai (2005) first reported $\mathrm{CO}_{2}$ exchange over the Sakaerat forest, showing, in general, negative net ecosystem exchange (uptake of carbon dioxide) in the wet season and positive net ecosystem exchange in the dry season. Considering the fact that soil respiration at Sakaerat is greatly reduced during the dry season (Yoda and Nishioka, 1982), the positive net ecosystem exchange in the dry season implies a significant decline in photosynthesis. This decline is due probably to soil water deficit, which primarily controls stomatal conductance of H. ferrea at Sakaerat (Pitman, 1996).

Although there have been several studies which corroborate the results of Pinker et al. (1980), it may not be appropriate to draw the conclusion that the Sakaerat forest evaporates more water in the wet season than in the dry season. Pinker et al. (1980) measured sensible heat flux at three layers above the canopy (32-36, 36-40, and 40-46-m) by a gradient method without stability correction functions, and gave the latent heat flux as a residual. As noted by Pinker et al. (1980), it may not be critical to use the method without diabatic corrections because of the prevailing neutral atmospheric conditions at the site. However, the layer choice greatly alters the estimated ET values particularly in the dry period of January (Fig. 5 in Pinker et al., 1980). This implies large uncertainties in the ET estimations by their study, and is the reason for being unable to explicitly refer the ET seasonality at Sakaerat in this publication.

Nobuhiro et al. (2007) made ET measurements at another dry evergreen forest site using the Bowen ratio method throughout the year (from November 2003 to October 2004) at Kampong Thom in Cambodia (see Fig. 1 and Table 2), showing that ET at their site was ca. $3.5 \mathrm{~mm} \mathrm{~d}^{-1}$ in both early and late dry season, and was ca. $2.0 \mathrm{~mm} \mathrm{~d}^{-1}$ in the wet season (not shown in Fig. 3, see Section 3.1). Though, for six trees at the Kampong Thom site, Daikoku et al. (2007) observed stomatal closure of individual leaves during the dry season, the elevated atmospheric evaporative demand in the same season (Section 2.1) is likely to exert greater influence on the stand-scale ET. Along with the atmospheric evaporative demand, both the deep soil (>4 m; Ohnuki et al., 2006) and high groundwater level (no deeper than $3 \mathrm{~m}$ even in the late dry season; Araki et al., 2007) at their site may play key roles in supporting the dry season ET.

\subsection{Deciduous forests}

Net radiation does not drastically decrease in the dormant (or dry) season (e.g., Toda et al., 2002) of deciduous forest ecosystems in the tropical monsoon climate as it does at temperate deciduous forests (e.g., Wilson and Baldocchi, 2000). However, because most deciduous trees in this climate are leafless during the dry season (see Section 2.2), the ET of deciduous tropical monsoon forests is expected to decrease in the dry season. In fact, Attarod et al. (2006) conducted longterm ET measurements by the Bowen ratio method at a teak deciduous forest site (Mae Moh; see Fig. 1 and Table 2) for the period of 1999-2004, and reported that the mean monthly ET reached a maximum of $4.1 \mathrm{~mm} \mathrm{~d}^{-1}$ in the mid growing season of September and attained a minimum of $2.5 \mathrm{~mm} \mathrm{~d}^{-1}$ in the dry season of February and March (Fig. 3).

Toda et al. (2002) observed water and energy exchanges over a disturbed dry dipterocarp forest site (Tak, see Fig. 1, see footnote $b$ in Table 2 for more description about this vegetation) for the period of June 1998 to February 1999. They employed the eddy covariance method to measure the sensible heat flux, and a bandpass eddy covariance method (e.g., Watanabe et al., 2000) for the latent heat flux. As a result, Toda et al. (2002) found that ET reached a maximum of $3.3 \mathrm{~mm} \mathrm{~d}^{-1}$ in the wet season of August, and declined to $0.6 \mathrm{~mm} \mathrm{~d}^{-1}$ (ca. $1.5 \mathrm{MJ} \mathrm{d}^{-1}$ ) in the dry season of February (Fig. 3). Net radiation in February at their site was $8.7 \mathrm{MJ} \mathrm{d}^{-1}$ on average, of which the sensible heat flux was estimated to be 3.3 $\mathrm{MJ} \mathrm{d}^{-1}$. Toda et al. (2002) discussed the accuracies of their flux estimations in detail, stressing incomplete energy closure of their data. For example, for February 1999, the residual term in the energy balance equation (net radiation minus total fluxes) was $3.4 \mathrm{MJ} \mathrm{d}^{-1}$, a value which is approximately two times greater than latent heat flux $\left(1.5 \mathrm{MJ} \mathrm{d}^{-1}\right)$ and is comparable to sensible heat flux $\left(3.3 \mathrm{MJ} \mathrm{d}^{-1}\right)$ in the same month. Since no further attempt was made to correct the energy imbalance in their study, one should refer to the flux estimates taking the imbalance into consideration.

\section{Responses to inter-annual variation in rainfall}

Inter-annual fluctuations in regional climate, such as delays of the Asian monsoon onset associated with ENSO events (Zhang et al., 2002) and reduced rainfall during these events (Malhi and Wright, 2004) may be significant in mainland SE Asia. These anomalies in regional precipitation result in substantial inter-annual variations not only in annual rainfall but also in the seasonal distribution of rainfall. In general, the stand-scale phenology of tropical monsoon forests may be controlled by the seasonality of rainfall (Corlett and LaFrankie, 1998), although there are many exceptions, particularly at the individual species level (e.g., Rivera et al., 2002; Elliot et al., 2006). Therefore, large inter-annual variations in regional rainfall might be followed by inter-annual variations in phenology of tropical monsoon forests at the regional scale. Yoshifuji et al. (2006) reported on the growing-season length at the Mae Moh teak deciduous forest for three consecutive years. Using the canopy radiative transmittance and sap flow velocity of teak trees, they determined the leaf period and transpiration period, respectively, for each year. As a result, they found that a substantial rain event of $117 \mathrm{~mm}$ over $6 \mathrm{~d}$ in the late dry season (pre-monsoon rainfall, see Section 2.1) advanced the timing of leaf flush and tree transpiration. On the other hand, a decrease in tree transpiration and resultant leaf fall were delayed as a result of the delayed withdrawal of the wet season. Consequently, the canopy duration and transpiration period differed among the three years by up to 40 and $60 \mathrm{~d}$, respectively (Yoshifuji et al., 2006). This year-toyear difference is much larger than the variation in growingseason lengths reported for temperate deciduous forests (e.g., 
Goulden et al., 1996; Wilson and Baldocchi, 2000; Granier et al., 2002; Saigusa et al., 2002), suggesting significant inter-annual variation in mass exchanges between deciduous tropical monsoon forests in this region and the atmosphere. However, the rain-induced leaf flushing and shedding of the teak leaves at Mae Moh probably does not represent the canopy phenology of all deciduous forests in this region. In fact, for a dry dipterocarp forest, Rundel and Boonpragob (1995) stated that new leaves begin forming before the end of the dry season. Furthermore, Ito et al. (2007) reported no clear seasonal change in LAI at a Cambodian dry dipterocarp forest, probably because the study area is located in a mesic site. In addition, Elliot et al. (2006) observed the patterns of leaf flushing and shedding for various deciduous tree species, reporting that spring flushing of deciduous trees was more common in this region; flushing was induced around the spring equinox by increasing day length. They suggested that rainfall may not be the dominant factor controlling tree phenology in this region. These results indicate that the canopy phenology of tropical monsoon forests is determined by various factors, rather than by a single factor such as temperature for temperate deciduous forests. Further investigations of inter-annual variations in canopy phenology and growing-season length are necessary.

Tree water use in tropical monsoon forests can also be influenced by inter-annual variation in seasonal distributions of rainfall, because a prolonged dry period causes severe moisture stress in trees. Kume et al. (2007) made long-term measurements of sap flow velocities of various sized trees in the Kog-Ma forest and reported that tree water use significantly decreased in a small sapling in the late dry season when shallow soils were extremely dry. In contrast, during the same dry period, tree water use of canopy trees did not show an apparent decrease. The differences in root development between saplings and canopy trees could be a reason for the different responses to soil water deficit. Owing to the active sap flow of canopy trees, stand-scale ET at the Kog-Ma forest remained high despite the prolonged seasonal drought (see Section 3.1).

\section{Discussions and concluding remarks}

To understand the roles of tropical monsoon forests in regional and global climate systems, this publication has summarised the region's forest types and reviewed studies related to evapotranspiration from these forests. Seasonal and inter-annual fluctuations in meteorological conditions are significant in this region. Reviewing previous studies, we paid much attention to how the respective forest ecosystems reacted to the two fluctuations with different timescales.

\subsection{Studied and unstudied forest types}

The six published studies that are listed in Table 2 do not cover all the forest types in this region (Table 1). Of the five tropical monsoon forest ecosystems, ET has not yet been examined at three ecosystems; the (undisturbed) dry dipterocarp forest, tropical wet evergreen forest, and (typical) mixed deciduous forest. Though the geographical distribution of tropical wet evergreen forest is restricted to a small area between the
Kangar-Pattani Line to the Isthmus of Kra in the Malaysian Peninsula (Fig. 1 and Section 2.2), both the dry dipterocarp forest and the mixed deciduous forest are widespread over the mainland SE Asia (Rundel and Boonpragob, 1995; Blasco, 1983; Section 2.2). As part of the AsiaFlux network, energy and $\mathrm{CO}_{2}$ fluxes at a typical mixed deciduous forest (Mae Klong site in Fig. 1; Gamo, 2003) are now being monitored, and forthcoming results may help fill the data gap. On the other hand, to our knowledge, there is no study site focusing on fluxes over undisturbed dry dipterocarp forests. Considering the large expanse of dry dipterocarp forest, water and energy exchanges of these forests with the atmosphere are expected to significantly influence the regional climate. Thus, future efforts to understand water and energy cycling of dry dipterocarp forest are particularly needed.

\subsection{Seasonality}

The atmospheric evaporative demand is maximised in the late dry season, and is lowered in the wet season in this monsoon climate (see Section 2.1, Fig. 2). Our current knowledge on how each forest type responds to seasonal change in evaporative demand is limited (Fig. 3, Sections 3.2-3.4). However, studies have shown that with increasing atmospheric evaporative demand, ET increases at two evergreen forests; the Kog-Ma hill evergreen forest and Kampong Thom dry evergreen forest. In contrast, ET likely declines in the dry season at the Sakaerat dry evergreen forest. Also, ET declines with increasing evaporative demand at two deciduous forest types of the Mae Moh teak deciduous forest and Tak disturbed dry dipterocarp forest. As a result of these different responses of tropical monsoon forests to the increased evaporative demand, the dry season ET values varies significantly among forest types, ranging from $0.6 \mathrm{~mm} \mathrm{~d}^{-1}$ at the Sakaerat dry evergreen to $5.9 \mathrm{~mm} \mathrm{~d}^{-1}$ at the Pang Khum secondary hill evergreen forest (Fig. 3). The low end of this range is likely the result of reduced stomatal conductance (Ishida et al., 2006; Pitman, 1996), while the high end of the range is likely caused by the horizontal advection of energy and deep rooting systems (Giambelluca et al., 2000). Compared with the large contrast in the dry season ET, the difference in the wet season ET among forest types was relatively small (Fig. 3). The magnitude of dry season ET is primary controlled by transpiration of individual trees. To draw a more general conclusion regarding the difference in dry season ET between forest types in this region, further efforts to examine the responses of stomatal conductance of individual trees to soil water deficit, high VPD, and high temperature are particularly needed.

It should be noted that the reviewed studies in this publication employed various techniques for measuring ET (discussed in Section 3) and were conducted in a variety of periods. Because inter-annual fluctuations in rainfall are significantly large in this region (see Section 4), the different study periods between the referred studies are critical when making inter-forest-type comparisons of ET. For example, the low dry season ET values of ca. $0.6 \mathrm{~mm} \mathrm{~d}^{-1}$ at Sakaerat and Tak sites were observed in January 1970 and February 1999, respectively, which were preceded by the 1968-70 and 199798 ENSO events. Given that these ENSO events are followed by 
low rainfall and high surface temperature (Section 1), it is inappropriate to consider the reported low ET as normal year values. In order to avoid such a problem derived from differences of methods and study periods, a long-term research program which monitors ET from various forest types using a consistent methodology are required to develop a more general understanding of the roles of tropical monsoon forests.

Lowland mixed dipterocarp forests, which are distributed over the equatorial region of SE Asia, have been much more studied with regard to ET. Since these forests are located in regions without a distinct dry period, the reported ET seasonality is relatively constant throughout the year (e.g., Tani et al., 2003a,b; Kumagai et al., 2005). On the other hand, a number of studies at Amazonian rainforests with an annual dry season (e.g., Araújo et al., 2002; Carswell et al., 2002; Rocha et al., 2004; Malhi et al., 2002; Miranda et al., 1997; von Randow et al., 2004) provide perspectives of future research in SE Asia. The reported ET seasonality in the Amazon is not consistent, but likely varies with site and year. For example, observations show lower dry season ET at a Brazilian cerrado (Miranda et al., 1997) and a terra firme forests in central Amazon (observed on in a normal year in terms of rainfall, Malhi et al., 2002). Dry season ET was nearly identical to wet season ET at terra firme forests in southwest Amazon (von Randow et al., 2004) and in central Amazon (observed in a wet year, Araújo et al., 2002), whereas higher ET in the dry season was observed for terra firme forests in eastern Amazon than in the wet season (Carswell et al., 2002; Rocha et al., 2004). These elevated dry season ET values were explained mainly by increased atmospheric evaporative demand (Carswell et al., 2002; Rocha et al., 2004) and, in part, by leaf flush in the corresponding season (Carswell et al., 2002). In addition, those studies stressed that the forests were able to extract soil water even in the dry season because of deep rooting-depths (Nepstad et al., 1994) or the nocturnal upward flow of soil water such as hydraulic lift (Rocha et al., 2004), or both. Similarly, in mainland SE Asia, indirect evidence (Tanaka et al., 2004; Ohnuki et al., 2006) suggests that deep rooting-depth is an important factor determining whether ET is elevated in the late dry season. Given the importance of rooting-depth, direct observations of the deep roots (e.g., Nepstad et al., 1994) in tropical monsoon forests are required. In addition, for a broader understanding of dry season ET of tropical monsoon forests in this region, efforts of mapping the spatial distribution of the rootingdepths over mainland SE Asia are needed, similar to the satellite-based study of rooting-depths in the Amazon Basin (Ichii et al., 2006).

\subsection{Inter-annual variability}

Inter-annual variations in rainfall and in seasonal distribution are also significant in the region, leading to severe droughts and irregular ecological rhythms of trees. Recent findings suggest that this inter-annual variation in rainfall is followed by phenological and physiological changes in the tropical monsoon forests (Yoshifuji et al., 2006; Kume et al., 2007). These responses may, in turn, influence mass exchanges between the forest ecosystems and the atmosphere. The effects of such year-to-year variations in rainfall on the hydro-meteorology of tropical monsoon forests remain less understood. Therefore, further research should also focus on the effects of anomalies of the rainfall regime, based on field observations in tropical monsoon forests.

\section{Acknowledgements}

This work was funded by the Core Research for Evolutional Science and Technology (CREST) program of the Japan Science and Technology (JST) Agency and the Global Energy and Water Cycle Experiment, by Asian Monsoon Experiment-Tropics (GEWEX/GAME-Tropics) project, which provided meteorological and flux data set at Tak site referred in this publication (http://hydro.iis.u-tokyo.ac.jp/GAME-T/), and by the Japanese Ministry of Education, Culture, Sports, Science and Technology, Grants-in-Aid for Scientific Research for Young Scientists (\#17780119). This study could not have been conducted without the cooperation of the Faculty of Forestry, Kasetsart University. We particularly thank Prof. Chunkao Kasem and Drs. Boonyawat Samakkee and Niyom Wicha. We are also grateful to insightful critiques and comments given by the editor and the two anonymous reviewers.

\section{R E F E R E N C E S}

Araki, M., Shimizu, A., Toriyama, J., Ito, E., Kabeya, N., Nobihiro, T., Tith, B., Pol, S., Lim, S., Khorn, S., Pith, P., Det, S., Ohta, S., Kanzaki, M., 2007. Changes of vertical soil moisture conditions of a dry evergreen forest in Kampong Thom, Cambodia. In: Sawada, H., Araki, M., Chappell, N.A., LaFrankie, J.V., Shimizu, A. (Eds.), Forest Environments in the Mekong River Basin. Springer, Tokyo, pp. 112-124.

Araújo, A.C., Nobre, A.D., Kruijt, B., Elbers, J.A., Dallarosa, R., Stefani, P., von Randow, C., Manzi, A.O., Culf, A.D., Gash, J.H.C., Valentini, R., Kabat, P., 2002. Comparative measurements of carbon dioxide fluxes from two nearby towers in a central Amazonian rainforest: the Manaus LBA site. J. Geophys. Res. 107 (D20), 8090, doi:10.1029/ 2001JD000676.

Ashton, P.S., 1990. Thailand: biodiversity center for the tropics of Indo-Burma. J. Sci. Soc. Thailand 16, 107-116.

Ashton, P.S., 1995. Towards a regional forest classification for the humid tropics of Asia. In: Box, E.O., Peet, R.K., Masuzawa, T., Yamada, I., Fujiwara, K., Maycock, P.F. (Eds.), Vegetation Science in Forestry. Kluwer Academic Publishers, Netherlands, pp. 453-464.

Attarod, P., Aoki, M., Komori, D., Ishida, T., Fukumura, K., Boonyawat, S., Tongdeenok, P., Yokoya, M., Punkngum, S., Pakoktom, T., 2006. Estimation of crop coefficients and evapotranspiration by meteorological parameters in a rainfed paddy rice field, cassava and teak plantations in Thailand. J. Agric. Meteorol. 62, 93-102.

Blasco, F., 1983. The transition from open forest to savanna in continental Southeast Asia. In: Bourlière, F. (Ed.), Tropical Savannas. Elsevier, Amsterdam, pp. 167-181.

Bøgh, A., 1996. Abundance and growth of rattans in Khao Chong National Park, Thailand. Forest Ecol. Manage. 84, 71-80.

Bruijnzeel, L.A., 1990. Hydrology of Moist Tropical Forests and Effects of Conversion: A State of Knowledge Review. International Hydrological Programme, UNESCO. 
Calder, I.R., Wright, I.R., Murdiyarso, D., 1986. A study of evaporation from tropical rain forest-West Java. J. Hydrol. 89, 13-31.

Carswell, F.E., Costa, A.L., Palheta, M., Malhi, Y., Meir, P., Costa, J.P.R., Ruivo, M.L., Leal, L.S.M., Costa, J.M.N., Clement, R.J., Grace, J., 2002. Seasonality in $\mathrm{CO}_{2}$ and $\mathrm{H}_{2} \mathrm{O}$ flux at an eastern Amazonian rain forest. J. Geophys. Res. 107 (D20), 8076, doi:10.1029/2000JD000284.

Choudhury, B.J., DiGirolamo, N.E., Susskind, J., Darnell, W.L., Gupta, S.K., Asrar, G., 1998. A biophysical process-based estimate of global land surface evaporation using satellite and ancillary data. II. Regional and global patterns of seasonal and annual variations. J. Hydrol. 205, 186-204.

Chunkao, K., Tangtham, N., Boonyawat, S., Niyom, W., 1981. 15Year Tentative Report 1966-1980: Watershed Management Research on Mountainous Land. Department of Conservation, Faculty of Forestry, Kasetsart University, Bangkok, Thailand.

Corlett, R.T., LaFrankie, J.V., 1998. Potential impacts of climate change on tropical Asian forests through an influence of phenology. Climate Change 39, 439-453.

Daikoku, K., Hattori, S., Deguchi, A., Fujita, Y., Araki, M., Nobuhiro, T., 2007. Stomatal response characteristics of dry evergreen and dry deciduous forests in Kampong Thom, Cambodia. In: Sawada, H., Araki, M., Chappell, N.A., LaFrankie, J.V., Shimizu, A. (Eds.), Forest Environments in the Mekong River Basin. Springer, Tokyo, pp. 97-111.

Elliot, S., Baker, P.J., Borchert, R., 2006. Leaf flushing during the dry season: the paradox of Asian monsoon forests. Global Ecol. Biogeogr. 15, 248-257.

FAO (Food and Agriculture Organization), 2001. Global Forest Resources Assessment 2000-Main Report. FAO Forestry Paper, 140, Rome.

Gamo, M., 2003. Measurement of net ecosystem production of a forest ecosystem using the eddy covariance method. NettaiRingyo 57, 7-16 In Japanese.

Gamo, M., Panuthai, S., 2005. Carbon flux observation in the tropical seasonal evergreen forest in Sakaerat, Thailand. AsiaFlux Newslett. 14, 4-6.

Giambelluca, T.W., 2002. Hydrology of altered tropical forest. Hydrol. Process. 16, 1665-1669.

Giambelluca, T.W., Nullet, M.A., Ziegler, A.D., Tran, L., 2000. Latent and sensible energy flux over deforested land surfaces in the eastern Amazon and northern Thailand. Singapore J. Trop. Geogr. 21, 107-130.

Giambelluca, T.W., Ziegler, A.D., Nullet, M.A., Truong, D.M., Tran, L.T., 2003. Transpiration in a small tropical forest patch. Agric. Forest Meteorol. 117, 1-22.

Goulden, M.L., Munger, J.W., Fan, S.-M., Daube, B.C., Wofsy, S.C., 1996. Exchange of carbon dioxide by a deciduous forest: response to interannual climate variability. Science 271 , 1576-1578.

Granier, A., Pilegaard, K., Jensen, N.O., 2002. Similar net ecosystem exchange of beech stands located in France and Denmark. Agric. Forest Meteorol. 114, 75-82.

Henderson-Sellers, A., Dickinson, R.E., Durbridge, T.B., Kennedy, P.J., McGuffie, K., Pitman, A.J., 1993. Tropical deforestation: modeling local- to regional-scale climate change. J. Geophys. Res. 98, 7289-7315.

Hirch, P., 1987. Deforestation and development in Thailand. Singapore J. Trop. Geogr. 8, 129-138.

Hirch, P., 1990. Forests, forest reserve, and forest land in Thailand. Geogr. J. 156, 166-174.

Ichii, K., Hashimoto, H., White, M.A., Potter, C., Hutyra, L.R., Huete, A.R., Myneni, R.B., Nemani, R.R., 2006. Constraining rooting depths in tropical rainforests using satellite data and ecosystem modeling for accurate simulation of gross primary production seasonality. Global Change Biol. 12, $1-11$.
Ishida, A., Diloksumpun, S., Ladpala, P., Staporn, D., Panuthai, S., Gamo, M., Yazaki, K., Ishizuka, M., Puangchit, L., 2006. Contrasting seasonal leaf habits of canopy trees between tropical dry-deciduous and evergreen forests in Thailand. Tree Physiol. 26, 643-656.

Ito, E., Khorn, S., Lim, S., Pol, S., Tith, B., Pith, P., Tani, A., Kanzaki, M., Kaneko, T., Okuda, Y., Kabeya, N., Nobuhiro, T., Araki, M., 2007. Comparison of the leaf area index (LAI) of two types of Dipterocarp forest on the west bank of the Mekong River, Cambodia. In: Sawada, H., Araki, M., Chappell, N.A., LaFrankie, J.V., Shimizu, A. (Eds.), Forest Environments in the Mekong River Basin. Springer, Tokyo, pp. 214-221.

Kajiya, Y., 2007. Seasonality in carbon, water, and energy exchanges with the atmosphere at two tropical monsoon forests in Thailand. Master's Thesis, The University of Tokyo, Tokyo, In Japanese.

Kanae, S., Oki, T., Mushiake, K., 2001. Impact of deforestation on regional precipitation over the Indochina peninsula. J. Hydrometeorol. 2, 51-70.

Kiguchi, M., Matsumoto, J., 2005. The rainfall phenomena during the pre-monsoon period over the Indochina Peninsula in the GAME-IOP year, 1998. J. Met. Soc. Jpn. 83, 89-106.

Kira, T., 1983. Ecology of Tropical Forests. Jimbunshoin, Kyoto, In Japanese.

Krishnapillay, B., 2000. Silviculture and management of teak plantations. Unasylva 201, 14-21.

Kumagai, T., Saitoh, T.M., Sato, Y., Morooka, T., Manfroi, O.J., Kuraji, K., Suzuki, M., 2004. Transpiration, canopy conductance and the decoupling coefficient of a lowland mixed dipterocarp forest in Sarawak, Borneo: dry spell effects. J. Hydrol. 287, 237-251.

Kumagai, T., Saitoh, T.M., Sato, Y., Takahashi, H., Manfroi, O.J., Morooka, T., Kuraji, K., Suzuki, M., Yasunari, T., Komatsu, H., 2005. Annual water balance and seasonality of evapotranspiration in a Bornean tropical rainforest. Agric. Forest Meteorol. 128, 81-92.

Kume, T., 2005. Studies on evapotranspiration in tropical evergreen forests in Southeast Asia using individual treescale sap flow measurements. Ph.D. Dissertation, The University of Tokyo, Tokyo.

Kume, T., Takizawa, H., Yoshifuji, N., Tanaka, K., Tanaka, N., Tantasirin, C., Suzuki, M., 2007. Impact of soil drought due to seasonal and inter-annual variability of rainfall on sap flow and water status of evergreen trees in a tropical monsoon forest in northern Thailand. Forest Ecol. Manage. 238, 220-230.

Kuraji, K., Punyatrong, K., Sirisaiyard, I., Tantasirin, C., Tanaka, N., 2007. Scale dependency of hydrological characteristics in the upper Ping River basin, northern Thailand. In: Sawada, H., Araki, M., Chappell, N.A., LaFrankie, J.V., Shimizu, A. (Eds.), Forest Environments in the Mekong River Basin. Springer, Tokyo, pp. 67-74.

Kuraji, K., Punyatrong, K., Suzuki, M., 2001. Altitudinal increase in rainfall in Mae Chaem watershed, Thailand. J. Met. Soc. Jpn. 79, 353-363.

Laurance, W.F., 1999. Reflections on the tropical deforestation crisis. Biol. Conserv. 91, 109-117.

Mabuchi, K., Sato, Y., Kida, H., 2005a. Climatic impact of vegetation change in the Asian tropical region. Part I. Case of the Northern Hemisphere summer. J. Climate 18, 410-428.

Mabuchi, K., Sato, Y., Kida, H., 2005b. Climatic impact of vegetation change in the Asian tropical region. Part II. Case of the Northern Hemisphere winter and impact on the extratropical circulation. J. Climate 18, 429-446.

Malhi, Y., Pegoraro, E., Nobre, A.D., Pereira, M.G.P., Grace, J., Culf, A.D., Clement, R., 2002. Energy and water dynamics of a central Amazonian rain forest. J. Geophys. Res. 107 (D20), 8061, doi:10.1029/2001JD000623. 
Malhi, Y., Wright, J., 2004. Spatial patterns and recent trends in the climate of tropical rainforest regions. Phil. Trans. R. Soc. Lond. Ser. B 359, 311-329.

Matsumoto, J., 1997. Seasonal transition of summer rainy season over Indochina and adjacent monsoon region. Adv. Atmos. Sci. 14, 231-245.

Miranda, A.C., Miranda, H.S., Lloyd, J., Grace, J., Francey, R.J., Mcintype, J.A., Meir, P., Riggan, P., Lockwood, R., Brass, J., 1997. Fluxes of carbon, water, and energy over Brazilian cerrado: an analysis using eddy covariance and stable isotopes. Plant Cell Environ. 20, 315-328.

Myers, N., 1994. Tropical forests: present status and future outlook. Climatic Change 19, 3-32.

Nepstad, D.C., de Carvalho, C.R., Davidson, E.A., Jipp, P.H., Lefebvre, P.A., Negreiros, G.H., da Silva, E.D., Stone, T.A., Trumbore, S.E., Vieira, S., 1994. The role of deep roots in the hydrological and carbon cycles of Amazonian forests and pastures. Nature 372, 666-669.

Nishida, K., Matsuda, S., Kanae, S., 2005. Response of land surface in Indian China Peninsula to rainfall, El Nino, and DME. J. Rem. Sens. Soc. Jpn. 25, 473-481 In Japanese with English summary.

Nobuhiro, T., Shimizu, A., Kabeya, N., Tsuboyama, Y., Kubota, T., Abe, T., Araki, M., Tamai, K., Chann, S., Keth, N., 2007. Year-around observation of evapotranspiration in an evergreen broadleaf forest in Cambodia. In: Sawada, H., Araki, M., Chappell, N.A., LaFrankie, J.V., Shimizu, A. (Eds.), Forest Environments in the Mekong River Basin. Springer, Tokyo, pp. 75-86.

NWPCD. (National Park, Wildlife and Plant Conservation Department), 2000. Preliminary Forest Land Use Assessment in 2000. Royal Forest Department, Bangkok. Available on line at http://www.forest.go.th/stat/stat45/ stat2545.htm.

Ogawa, H., Yoda, K., Kira, T., 1961. A preliminary survey of the vegetation of Thailand. Nat. Life Southeast Asia 1, 21-157.

Ogawa, H., Yoda, K., Kira, T., Ogino, K., Shidei, T., Ratanawongse, D., Apasutaya, C., 1965. Comparative ecological study on three main types of forest vegetation in Thailand. I. Structure and floristic composition. Nat. Life Southeast Asia 4, 13-48.

Ogino, K., 1976. Human influences on the occurrence of deciduous forest vegetation in Thailand. Memoirs of the College of Agriculture Kyoto University, 108, p. 55-74.

Ohnuki, Y., Kimhean, C., Toriyama, J., Shinomiya, Y., 2006. Evaluation of the soil depth at evergreen-deciduous-mixed forests in Kampong Thom Province, Cambodia. In: Proceedings of International Conference on Mekong Research for the People of the Mekong, Chiang Rai, Thailand, pp. 147-153.

Ohsawa, M., 1993. Latitudinal pattern of mountain vegetation zonation in southern and eastern Asia. J. Veg. Sci. 4, 13-18.

Ohsawa, M., 1995. The montane cloud forest and its gradational changes in Southeast Asia. In: Hamilton, L.S., Juvik, J.O., Scatena, F.N. (Eds.), Tropical Montane Cloud Forest. Springer-Verlag, New York, pp. 254-265.

Pendleton, R.L., 1962. Thailand: Aspects of Landscape and Life. Duell, Sloan and Pearce, New York.

Pinker, R.T., Thompson, O.E., Eck, T.F., 1980. The energy balance of a tropical evergreen forest. J. Appl. Meteorol. 19, 13411350.

Pitman, J.I., 1996. Ecophysiology of tropical dry evergreen forest, Thailand: measured and modelled stomatal conductance of Hopea ferrea, a dominant canopy emergent. J. Appl. Ecol. 33, 1366-1378.

Rivera, G., Elliot, S., Caldas, L.S., Nicolossi, G., Caradin, V.T.R., Borchert, R., 2002. Increasing day-length induces spring flushing of tropical dry forest trees in the absence of rain. Trees 16, 445-456.
Rocha, H.R., Goulden, M.L., Miller, S.D., Menton, M.C., Pinto, L.D.V.O., Freitas, H.C., Figueira, A.M.S., 2004. Seasonality of water and heat fluxes over a tropical forest in eastern Amazonia. Ecol. Appl. 14, S22-S32.

Ruangpanit, N., 1995. Tropical seasonal forests in monsoon Asia: with emphasis on continental Southeast Asia. Vegetatio 121, 31-40.

Rundel, P.W., Boonpragob, K., 1995. Dry forest ecosystem of Thailand. In: Bullock, S.H., Mooney, H.A., Medina, E. (Eds.), Seasonally Dry Tropical Forests. Cambridge University Press, Cambridge, pp. 93-123.

Saigusa, N., Yamamoto, S., Murayama, S., Kondo, H., Nishimura, N., 2002. Gross primary production and net ecosystem exchange of a cool-temperate deciduous forest estimated by the eddy covariance method. Agric. Forest Meteorol. 112, 203-215.

Santisuk, T., 1988. An Account of the Vegetation Northern Thailand. Franz Steiner Verlag Weisbaden $\mathrm{GmbH}$, Stuttgart.

Shuttleworth, W.J., 1988. Evaporation from Amazonian rainforest. Proc. R. Soc. Lond. B Biol. Sci. 233, 321-346.

Stott, P.A., Goldammer, J.G., Werner, W.L., 1990. The role of fire in the tropical lowland deciduous forests of Asia. In: Goldammer, J.G. (Ed.), Fire in the Tropical Biota. SpringerVerlag Berlin, Heidelberg, Germany, pp. 32-44.

Takanashi, S., Kosugi, Y., Tani, M., Matsuo, N., Mitani, T., Nik, A.R., 2005. Characteristics of the gas exchange of a tropical rain forest in Peninsular Malaysia. Phyton 45, 61-66.

Takanashi, S., Tani, M., Nik, A.R., 2003. Characteristics of transpiration over a tropical rainforest in Peninsular Malaysia. J. Jpn. Soc. Reveg. Technol. 29, 51-55 In Japanese with English summary.

Tanaka, K., 2002. Multi-layer model of $\mathrm{CO}_{2}$ exchange in a plant community coupled with the water budget of leaf surfaces. Ecol. Modell. 147, 85-104.

Tanaka, N., Kuraji, K., Tantasirin, C., Takizawa, H., Tangtham, N., Suzuki, M., in press. Relationships between rainfall, fog and throughfall at a hill evergreen forest site in northern Thailand. In: Bruijnzeel, L.A., Scatena, F.N., Hamilton, J.G., Juvik, J.O., Bubb, P. (Eds.), Mountains in the Mist: Science for Conserving and Managing Tropical Montane Cloud Forests. University of Hawaii Press, Honolulu.

Tanaka, K., Takizawa, H., Kume, T., Xu, J., Tantasirin, C., Suzuki, M., 2004. Impact of rooting depth and soil hydraulic properties on the transpiration peak of an evergreen forest in northern Thailand in the late dry season. J. Geophys. Res. 109 (D23), 107, doi:10.1029/2004JD004865.

Tanaka, K., Takizawa, H., Tanaka, N., Kosaka, I., Yoshifuji, N., Tantasirin, C., Piman, S., Suzuki, M., Tangtham, N., 2003. Transpiration peak over a hill evergreen forest in northern Thailand in the late dry season: assessing the seasonal changes in evapotranspiration using a multilayer model. J. Geophys. Res. 108 (D17), 4533, doi:10.1029/2002JD003028.

Tanaka, N., Tantasirin, C., Kuraji, K., Suzuki, M., Tangtham, N., 2005. Inter-annual variation in rainfall interception at a hill evergreen forest in northern Thailand. Bull. Tokyo Univ. Forests 113, 11-44.

Tani, M., Nik, A.R., Ohtani, Y., Yasuda, Y., Sahat, M.M., Kasran, B., Takanashi, S., Noguchi, S., Yusop, Z., Watanabe, T., 2003a. Characteristics of energy exchange and surface conductance of a tropical rain forest in Peninsular Malaysia. In: Okuda, T., Manokaran, N., Matsumoto, Y., Niiyama, K., Thomas, S.C., Ashton, P.S. (Eds.), Ecology of a Lowland Rain Forest in Southeast Asia. Springer-Verlag, Tokyo, pp. 73-88.

Tani, M., Nik, A.R., Yasuda, Y., Noguchi, S., Shamsuddin, S.A., Sahat, M.M., Takanashi, S., 2003b. Long-term estimation of evapotranspiration from a tropical rain forest in Peninsula Malaysia. In: Franks, S., Blöschl, G., Kumagai, M., Mushiake, K., Rosbjerg, D. (Eds.), Water Resources Systems-Water 
Availability and Global Change, IAHS Publication no. 280, pp. 267-274.

Thompson, O.E., Pinker, R.T., 1975. Wind and temperature profile characteristics in a tropical evergreen forest in Thailand. Tellus 27, 562-573.

Toda, M., Nishida, K., Ohte, N., Tani, M., Mushiake, K., 2002. Observations of energy fluxes and evapotranspiration over terrestrial complex land covers in the tropical monsoon environment. J. Met. Soc. Jpn. 80, 465-484.

von Randow, C., Manzi, A.O., Kruijt, B., de Oliveira, P.J., Zanchi, F.B., Silva, R.L., Hodnett, M.G., Gash, J.H.C., Elbers, J.A., Waterloo, M.J., Cardoso, F.L., Kabat, P., 2004. Comparative measurements and seasonal variations in energy and carbon exchange over forest and pasture in south west Amazonia. Theor. Appl. Climatol. 78, 5-26.

Vourlitis, G.L., Filho, N.P., Hayashi, M.M.S., Nogueira, J.S., Caseiro, F.T., Campelo Jr., J.H., 2001. Seasonal variations in the net ecosystem $\mathrm{CO}_{2}$ exchange of a mature Amazonian transitional tropical forest (cerradão). Funct. Ecol. 15, 388395.

Watanabe, T., Yamanoi, K., Yasuda, Y., 2000. Testing of the bandpass eddy covariance method for a long-term measurement of water vapour flux over a forest. Bound. Layer Meteorol. 96, 473-491.
Werner, W.L., Santisuk, T., 1993. Conservation and restoration of montane forest communities in Thailand. In: Lieth, H., Lohmann, M. (Eds.), Restoration of Tropical Forest Ecosystems. Kluwer Academic Publishers, Netherlands, pp. 193-202.

Whitmore, T.C., 1984. Tropical rainforests of the Far East, second ed. Clarendon Press, Oxford.

Wilson, K.B., Baldocchi, D.D., 2000. Seasonal and interannual variability of energy fluxes over a broadleaved temperate deciduous forest in North America. Agric. Forest Meteorol. 100, 1-18.

Yoda, K., Nishioka, M., 1982. Soil respiration in dry and wet seasons in a tropical dry-evergreen forest in Sakaerat, NE Thailand. Jpn. J. Ecol. 32, 539-541.

Yoshifuji, N., Kumagai, T., Tanaka, K., Tanaka, N., Komatsu, H., Suzuki, M., Tantasirin, C., 2006. Inter-annual variation in growing season length of a tropical seasonal forest in northern Thailand. Forest Ecol. Manage. 229, 333-339.

Zhang, Y., Bin Wang, T.L., Wu, G., 2002. Onset of the summer monsoon over the Indochina Peninsula: climatology and interannual variations. J. Climate 15, 3206-3221.

Zhang, H., Henderson-Sellers, A., McGuffie, K., 1996. Impacts of tropical deforestation. Part I. Process analysis of local climatic change. J. Climate 9, 1497-1517. 